\title{
O mundo em uma sala - quando o português chama
}

\author{
Pietra Da Ros* \\ Lovani Volmer** \\ Rosemari Lorenz Martins***
}

Resumo

Este estudo embasa-se na concepção de língua como prática social e considera-a fator determinante para a inserção social e sinônimo de identidade. Nesse sentido, pretende discutir, com base em atividades realizadas com migrantes e refugiados em um projeto de extensão universitária - $\mathbf{O}$ mundo em NH: refugiados e migrantes - uma questão de Direitos Humanos -, a importância da língua como acolhimento e construção de identidade. Para tanto, contextualiza-se o projeto e seus atores, assim como o ambiente multicultural e multilíngue em que são desenvolvidas as oficinas, em especial as de língua portuguesa, em uma perspectiva dialógica, com foco na comunicação como facilitadora para a realização das demais atividades e como premissa para a constituição identitária.

Palavras-chave: Língua portuguesa. Português como língua de acolhimento. Refugiados e migrantes. Identidade. Extensão universitária.

\footnotetext{
* Universidade Feevale. Graduanda de licenciatura em Letras - Português/Inglês. Bolsista do projeto CEDUCA DH.

** Universidade Feevale. Doutora em Letras, com ênfase em Leitura e Linguagens. Professora dos cursos de Letras e Pedagogia, professora extensionista nos projetos CEDUCA DH, Da Rua ParaNoia e Jovem Aprendiz Feevale.

** Universidade Feevale. Doutora em Letras. Professora do programa em Diversidade Cultural e Inclusão Social e do Curso de Letras.
} 


\title{
The world in a room - when Portuguese calls
}

\begin{abstract}
This study is based on the conception of language as a social practice and considers it a determining fator for social insertion and synonymous with identity. In this sense, it intends to discuss, based on the activities carried out with migrants and refugees in a university extension project - $\mathbf{O}$ mundo em NH: refugiados e migrantes - uma questão de Direitos Humanos - , the importance of language as a host and in building identity. To this end, the Project and its actors are contextualizes, as well as the multicultural and multilingual environment in which the workshops are developed, especially those of Portuguese Language, from a dialogical perspective, focusing on communication as a facilitator for the realization of other activities and as a premise for the identity construction.
\end{abstract}

Keywords: Portuguese Language. Portuguese as host language. Refugees and migrants. Identity. University extension.

Recebido em: 08/03/2021 // Aceito em: 20/04/2021. 


\section{Introdução}

Almeida Filho (2005, p. 12) sintetiza a história da língua portuguesa de maneira clara e interessante. Conforme o autor, o português europeu aportou no Brasil em 1500 como uma língua estrangeira. Em 1808, alcançou o status de língua nacional de amplo uso, durante o período imperial. Já no século XX, o português firmou-se como língua presente em quatro continentes, sendo oficial em oito países. De entre cerca de três mil línguas vivas hoje, a língua portuguesa é a sexta mais falada - isso se deve, principalmente, à sua densidade demográfica.

Contudo, a forma como é falado o português não é igual em todos os lugares. Fala-se uma variedade no Rio Grande do Sul e outra na Bahia. Mas não é preciso ir tão longe: existe variação entre a língua falada nos centros das cidades e nas periferias, na falada entre os jovens e os adultos, em momentos mais formais e informais. É a partir dessa língua, diferente em cada lugar em que é falada, que trabalhamos. Nesse sentido, embasado na concepção de língua como prática social, este estudo pretende discutir, a partir de vivências em um projeto de extensão universitária, mais especificamente, em oficinas de língua portuguesa para migrantes e refugiados, um ambiente multicultural e multilíngue, a importância da língua como acolhimento e para a construção de identidade.

\section{Sobrevoando: o projeto $\mathrm{O}$ mundo em NH}

Na região metropolitana de Porto Alegre/RS, atualmente, vive um número expressivo de refugiados e migrantes de 
diferentes nacionalidades, em especial, senegaleses, haitianos, angolanos, colombianos e venezuelanos, que trabalham ou estão à procura de emprego. Essa nova realidade, em um processo de migrações, fuga de áreas em conflito e miséria, instaurou uma nova demanda: a constituição de grupos de apoio a esses migrantes e refugiados que chegam ao Brasil.

Nesse contexto, visando à promoção de uma cultura de paz e tolerância, através do acolhimento e da inserção social de grupos de refugiados e migrantes e da articulação de ações educativas voltadas aos Direitos Humanos, contribuindo para a construção de uma sociedade que exerça cotidianamente sua cidadania, foi criado, em 2016, na Universidade Feevale, em Novo Hamburgo/RS, o projeto de extensão O mundo em NH: refugiados e migrantes - uma questão de Direitos Humanos. O projeto atende semanalmente migrantes e refugiados de diversas nacionalidades e culturas, que vieram ao Brasil em busca de melhores condições de vida e trazem consigo as mais diversas demandas, entre elas, pouco ou nenhum conhecimento de língua portuguesa.

$\mathrm{Na}$ prática, o migrante ou refugiado que têm interesse em se beneficiar do projeto deve ir, em uma quarta-feira à noite, ${ }^{1}$ à Universidade, onde, a partir das $19 \mathrm{~h} 30$, ocorrem oficinas. $\mathrm{Na}$ primeira parte da noite (das $19 \mathrm{~h} 30$ às $21 \mathrm{~h}$ ), acontecem as oficinas de língua portuguesa, cujo objetivo principal é a aprendizagem do português, língua oficial em nosso país. Em seguida, das $21 \mathrm{~h}$ às $22 \mathrm{~h} 15$, intercalam-se oficinas de história e cultura do Brasil, criatividade e psicologia, em que são abordadas, em português, temáticas específicas e de interesse dos beneficiados. Além disso, aqueles que participam do projeto têm, também, caso necessitem,

1 Em tempo de pandemia, os encontros estão acontecendo via Google Meet e Blackboard. 
à sua disposição, assessoramento jurídico e psicossocial, bem como encaminhamentos, quando necessário, à área da saúde.

Desde que foi criado, cerca de 80 migrantes e refugiados já participaram das aulas de português - a média de frequência semanal é entre 15 e 20 alunos, com idades entre 7 e 45 anos, visto que famílias inteiras frequentam o projeto. Trata-se, pois, de alunos provenientes de diferentes países, falantes de diferentes línguas e, em sua maioria, bilíngues ou multilíngues. A turma, cabe destacar, é miscigenada em muitos sentidos: culturas, vivências, idade e, também, níveis de escolaridade - alguns são analfabetos funcionais, outros pós-graduados. No que tange à língua portuguesa, unem-se, todos, em busca de um mesmo objetivo: aprender e/ou aperfeiçoar o português brasileiro.

Considerando se tratar de um projeto de extensão universitária, as aulas de língua portuguesa são planejadas por acadêmicos bolsistas do curso de Letras em conjunto com uma professora do curso, integrante do projeto, que também acompanha as aulas. Para que as oficinas de língua portuguesa ocorram, são realizadas reuniões semanais para estudo e planejamento. O planejamento parte da concepção de língua como prática social, de modo que o outro tem papel primordial na construção de identidade do próprio sujeito, uma vez que este só se constitui a partir daquele, ou seja, do discurso do outro.

\section{Percorrendo caminhos: o português como língua de acolhimento}

Compreender a linguagem como instrumento de mediação para a constituição do sujeito significa que não há sujeito pronto, mas que ele vai se completando em suas falas e nas falas do 
outro, de modo que tudo o que chega à consciência do sujeito chega através do outro. Nesse contexto, conforme a concepção bakhtiniana, quando o sujeito se apropria das palavras do outro, apropria-se do significado e da expressividade e não das palavras da língua.

Para a comunicação dos migrantes e refugiados que chegam ao Brasil, a língua portuguesa é a base, mas a maioria deles tem pouca ou nenhuma noção de português. Assim sendo, para que sejam aceitos e possam participar da comunidade, é imprescindível que aprendam a falar essa língua, pois precisarão dela não só para se comunicar, mas para poderem se constituir como sujeitos nesse novo contexto em que estão se inserindo. Conforme Buors e Lentz (2009), a aprendizagem de uma língua possibilita adquirir não só competências linguísticas como, também, saberes sociais para que possam ser e agir no mundo de maneira crítica.

Uma pesquisa realizada com os beneficiados do projeto corrobora essa premissa: $100 \%$ deles afirmaram que conhecer a língua é importante para se inserir na sociedade e "para poder viver a vida de forma plena no Brasil" (registro de um dos entrevistados). A fala de uma migrante palestina, beneficiada do projeto, contribui nesse sentido:

[...] nos dois primeiros anos em que estive no Brasil, senti que não vivia. Eu não me comunicava, não tinha comunicação. Não podia levar meus filhos no hospital, porque não conseguia falar. Era difícil ir ao mercado, fazer coisas simples. É como se eu não tivesse existido naqueles dois anos. (Migrante palestina, 38 anos, há 18 anos no Brasil).

Essa fala corrobora a teoria de Bakhtin de que o sujeito se constitui pela e na linguagem, assim como a ideia de que 
é preciso haver interação com outros sujeitos para que essa constituição aconteça. Ademais, o fato de não interagir fez com que a migrante palestina não se desenvolvesse e não se inserisse na comunidade à qual pertencia apenas fisicamente, demonstrando que, para existir, é preciso agir.

Nas palavras de outra migrante, colombiana:

[...] parece que, quando chegamos, todos estão numa bolha, num filme, e a gente assiste de longe. É difícil entrar nessa bolha para se comunicar, se sentir parte, mas como a gente vai aprendendo português, a gente consegue, e quando sabe dizer o que tem vontade é mais fácil, está dentro da bolha. (Migrante colombiana, 27 anos, há um ano no Brasil).

Nesse contexto, para além de um meio de comunicação, a palavra proferida é, no sentido bakhtiniano, também conteúdo da própria constituição humana. Além disso, a ambientação no país é firmada por meio da língua, que amplia as chances de buscar emprego, prosseguir com os estudos ou mesmo viver o cotidiano, compreender e ser compreendido.

Então, embora os migrantes e refugiados já tenham se constituído como sujeitos, pois já falam uma ou mais línguas, precisam, necessariamente, reconstruir ou complementar sua identidade, pois a comunidade da qual agora fazem parte possui outros valores, outras formas de significar. Nesse sentido, o enfoque nas aulas de português para migrantes e refugiados parte da necessidade da comunicação como facilitadora para a realização das demais atividades e como premissa para sua constituição identitária.

Importante considerar, ainda, que muitos dos participantes, antes de chegarem ao Brasil, já viveram em outros países e, por isso, aprenderam a falar outras línguas - muitos haitianos, por 
exemplo, em sua rota de fuga, já tiveram contato com o espanhol, então, além do francês e do crioulo haitiano, sua língua materna, têm também noção dessa língua. Além disso, aqueles oriundos de países do continente africano falam, no geral, além do inglês e/ou do francês, línguas crioulas, assim como os falantes do continente asiático, filipinos e palestinos, que, além de sua língua materna, falam também inglês.

É nesse ambiente multicultural e multilíngue que ocorrem as aulas de língua portuguesa, cujo foco é o uso da língua no âmbito social e comunicativo, em que, seguindo a concepção freireana, todos ensinam e todos aprendem:

[...] creio poder afirmar [...] que toda prática educativa demanda a existência de sujeitos, um que, ensinando, aprende, outro que, aprendendo, ensina, daí o seu cunho gnosiológico; a existência de objetos, conteúdos a serem ensinados e aprendidos; envolve o uso de métodos, de técnicas, de materiais; implica, em função de seu caráter diretivo, objetivo, sonhos, utopias, ideais. Daí a sua politicidade, qualidade que tem a prática educativa de ser política, de não poder ser neutra. (FREIRE, 2004, p. 41).

Partindo dessa premissa, para a efetivação das aulas, não se usa livro didático ou apostilas. Considerando-se o alinhamento construtivo (BIGGS; TANG, 2007), os encontros são planejados conforme o perfil, os interesses e as necessidades dos alunos, avançando, gradativamente, nas especificidades da língua. Dessa forma, aos poucos, o português vai se tornando mais harmônico aos ouvidos e facilitando a comunicação em seu cotidiano.

Esse contexto também fornece insumos para pesquisas acadêmicas. Cita-se como exemplo o estudo Influências interlinguísticas da língua materna na aquisição fonológica do Português Brasileiro (PB) como língua adicional em 
contexto multilíngue, que teve como objetivo identificar influências interlinguísticas da língua materna de três participantes bilíngues/multilíngues do projeto em sua fala em português (um turco, um haitiano e um venezuelano). A coleta dos dados deu-se por meio da leitura oral de um texto por cada um dos participantes. A leitura desses textos foi gravada. Todos os dados foram transcritos e analisados fonologicamente. Uma análise preliminar mostra que o turco, que fala turco e inglês, neutraliza a vibrante múltipla (produz r-fraco em lugar de r-forte ou apaga esse fonema), dessonoriza a fricativa dental/z/ e possui dificuldades para produzir os ditongos nasais; o haitiano, que fala um crioulo, também neutraliza a vibrante múltipla ou a troca por /1/ e também possui dificuldades para produzir o ditongo nasal; o venezuelano, por fim, também possui dificuldades para produzir o ditongo nasal e, além disso, troca a fricativa labial sonora /v/ pela oclusiva labial /b/. Destaca-se que esse trabalho está em fase de desenvolvimento, de modo que outras influências ainda podem ser encontradas, mas já trouxe subsídios importantes ao planejamento docente.

Ainda em relação à aquisição do português, embora a maioria dos migrantes e refugiados chegue com pouquíssimos conhecimentos de português ao projeto, alguns já conseguiram aprovação no Celpe-Bras - Certificado de Proficiência em Língua Portuguesa para Estrangeiros. ${ }^{2}$ Esses alunos continuam participando das aulas e servem de inspiração àqueles que chegaram há menos tempo e, por vezes, apresentam dificuldades para compreender, falar e/ou escrever em português.

2 O exame é aplicado semestralmente, no Brasil e no exterior, pelo Ministério da Educação (MEC), por meio do Instituto Nacional de Estudos e Pesquisas Educacionais Anísio Teixeira (Inep), em parceria com o Ministério das Relações Exteriores (MRE). 
No que diz respeito ao planejamento, ainda, é preciso considerar que, especialmente quando fazia muito frio ou chovia, muitos alunos não mantinham a assiduidade, pois as questões climáticas, aliadas às econômicas, faziam com que optassem por ficar protegidos. Assim sendo, o grupo, a cada semana, podia ser bem variado, o que exigia um planejamento flexível e dinamicidade dos acadêmicos que ministravam as aulas. Essa falta de regularidade ainda se mantém, mas, agora, em decorrência de dificuldades de acesso à internet, pois, em tempos de isolamento social em função da pandemia de Covid 19, as aulas não estão acontecendo presencialmente, mas de forma virtual. Semanalmente, no mesmo dia da aula, os encontros acontecem via Google Meet e os beneficiados recebem, pelo WhatsApp, materiais e dicas para que possam, mesmo em tempos adversos, continuar ampliando seus conhecimentos linguísticos. Dessa forma, a língua, para além de um conteúdo que precisa ser aprendido, é acolhimento, é a possibilidade de olhar para o outro e considerar o momento e suas necessidades para, a partir desses elementos, planejar o que será proposto e a melhor forma de fazê-lo.

Assim como as aulas de português se adaptaram, por exemplo, às circunstâncias impostas pela Covid 19, as oficinas também se adaptam aos costumes religiosos de cada participante, uma vez que há, na mesma sala, crenças adventistas, muçulmanas e mórmons, bem como o ateísmo. Por causa disso, os planos de aula estruturam-se em um dos pilares do projeto: a empatia. Cita-se como exemplo uma situação em que estava planejado abordar em determinada aula a variedade de comidas típicas do estado do Rio Grande do Sul, mas, como essa aula cairia no período de jejum dos muçulmanos, o Ramadã, o planejamento foi revisto e a atividade ocorreu em outro momento. 
A seguir, no intuito de elucidar ainda mais as ações e contribuições do projeto no que diz respeito à língua como acolhimento, à cidadania e à construção de identidade dos sujeitos que dele participam, explicitam-se alguns projetos realizados durante as oficinas de língua portuguesa.

\section{Com a língua e para além dela: buscando a expressão através de autorretratos e minicontos}

Nesta seção, são apresentados dois projetos desenvolvidos com a turma em tempos de aula presencial, antes da pandemia, a fim de expor metodologias utilizadas e analisar os resultados obtidos.

O projeto Autorretratos, assim como o título sugere, tinha como objetivo a realização, nas oficinas de língua portuguesa, de autorretratos com palavras, visando a um olhar sobre si e, especificamente no que diz respeito à língua, à ampliação do vocabulário e ao desenvolvimento da expressão oral. Assim, inicialmente, os alunos foram desafiados a criar, a partir das letras de seu nome e usando adjetivos positivos que lhes identificassem, um acróstico. Para tanto, foram distribuídos folhas, canetas coloridas, lápis de cor, tecidos e papéis coloridos.

Concluída a atividade, foi organizado um varal poético e cada um apresentou oralmente sua criação. Todos os adjetivos foram sendo anotados no quadro e novas palavras foram naturalmente surgindo e sendo explicadas. Além disso, discutiram-se especificidades da língua e a impossibilidade de, por vezes, a tradução ser efetiva na significação. Por fim, traçouse, em conjunto, o perfil da turma, estabelecendo semelhanças e diferenças entre os participantes. Essa atividade também 
possibilitou que fossem discutidas expressões típicas do Rio Grande do Sul, como "tri", "bagual", "borracho", "faceiro", "xiru", "xucro", entre outras, que foram aparecendo no momento de socialização das palavras, por já terem sido ouvidas por um ou outro participante.

A Figura 1, que segue, traz alguns dos textos, que, além de ampliar o vocabulário, possibilitaram aos participantes conhecerem-se um pouco mais e, com palavras positivas, elevarem sua autoestima.

\section{Figura 1 - Acróstico}

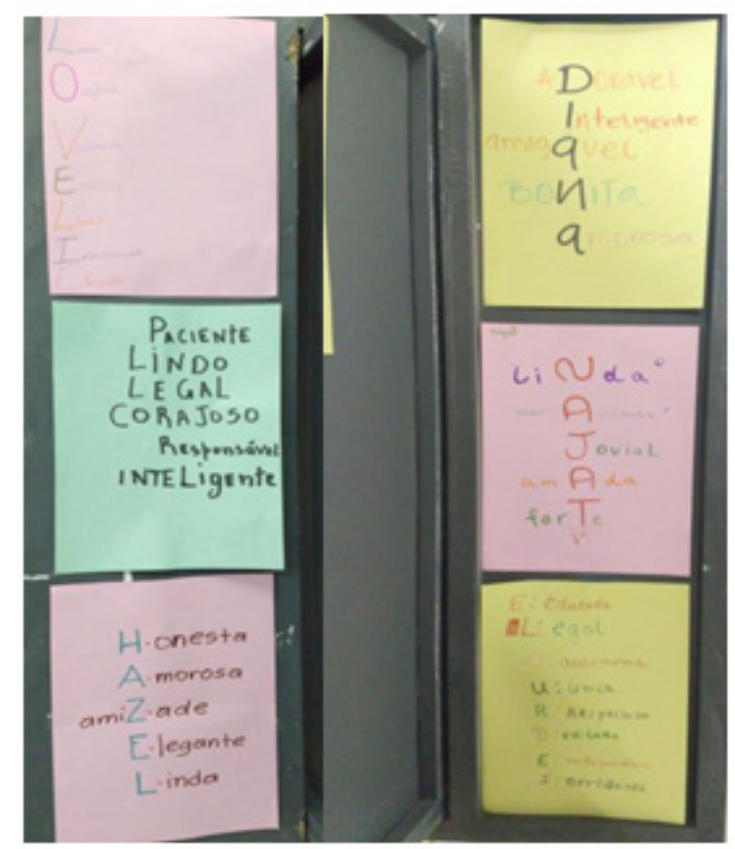

Fonte: Elaborado pelas autoras

Esses acrósticos foram reproduzidos e compartilhados com alunos de uma escola pública municipal da cidade, que estava 
estudando a temática da migração e havia feito contato com o projeto para que fossem realizadas atividades junto aos alunos. Representantes da escola (professores e estudantes) vieram até a instituição para conhecer um pouco mais sobre o Mundo em NH e levaram consigo os acrósticos, que foram distribuídos entre os alunos da turma da escola. A ideia era cada aluno escrever uma carta de boas-vindas ao Brasil para seu "amigo migrante secreto".

Paralelamente à atividade das cartas, que não era de conhecimento dos migrantes, as aulas ocorriam normalmente às quartas-feiras à noite. Assim, no encontro posterior à produção dos acrósticos, foram lidos, analisados, estudados, trabalhados os poemas "Retrato", de Cecília Meireles, "O autorretrato", de Mário Quintana, e “Autorretrato”, de Juca Chaves. Explorou-se o vocabulário, a sonoridade, o ritmo e a melodia de cada um dos textos, que foram livremente recitados pelos alunos.

Ainda, no intuito de explorar a sonoridade das palavras e a consciência fonológica, propôs-se, elaborado pelos bolsistas e pela professora, um jogo, dominó silábico (Figura 2), o qual consistia em juntar os desenhos cujos nomes começassem com a mesma sílaba (a imagem do pato unia-se à do palhaço, por exemplo). 


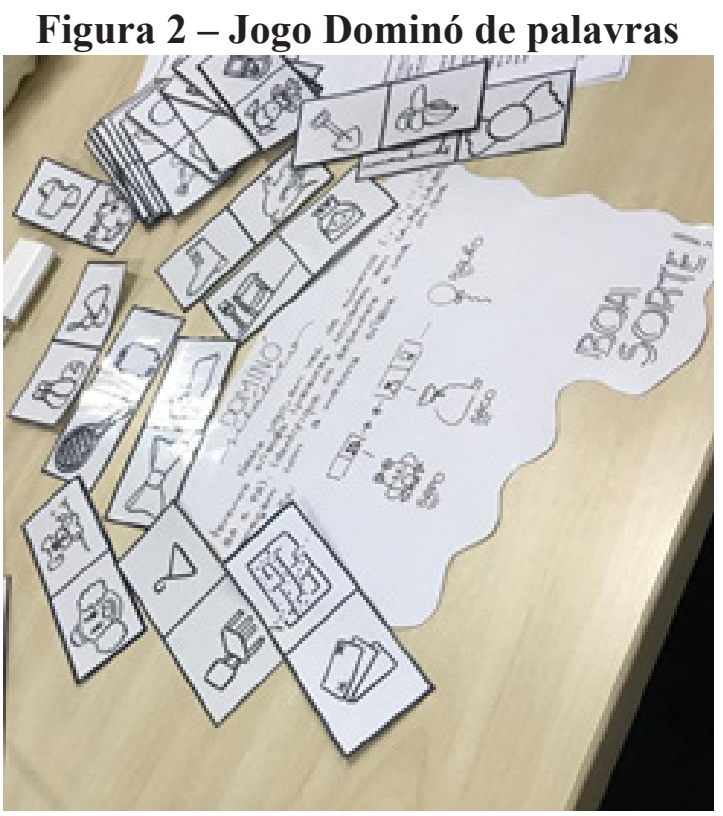

Fonte: Elaborado pelas autoras

$\mathrm{Na}$ etapa seguinte, o desafio foi brincar com as palavras e, com elas, criar um autorretrato. Com a mesma disponibilidade de materiais que tiveram quando da construção dos acrósticos, os participantes tomaram a liberdade de escreverem-se. O jogo de palavras e a escolha por aquelas que melhor definiam cada um naquele momento são, também, parte da construção identitária, especialmente em uma segunda, terceira ou quarta língua, como é o caso de muitos dos participantes do projeto.

Após escritos e reescritos, todos recitaram, com orgulho, seus escritos, os quais, mais que possibilitar conhecer um pouco mais a língua portuguesa, possibilitaram-lhes escrever e reescrever parte de si, suas memorescências. As Figuras 3 e 4 trazem exemplos dessa tessitura, alinhavada pela essência de cada um. 


\section{Figura 3 - Tenho orgulho disso}
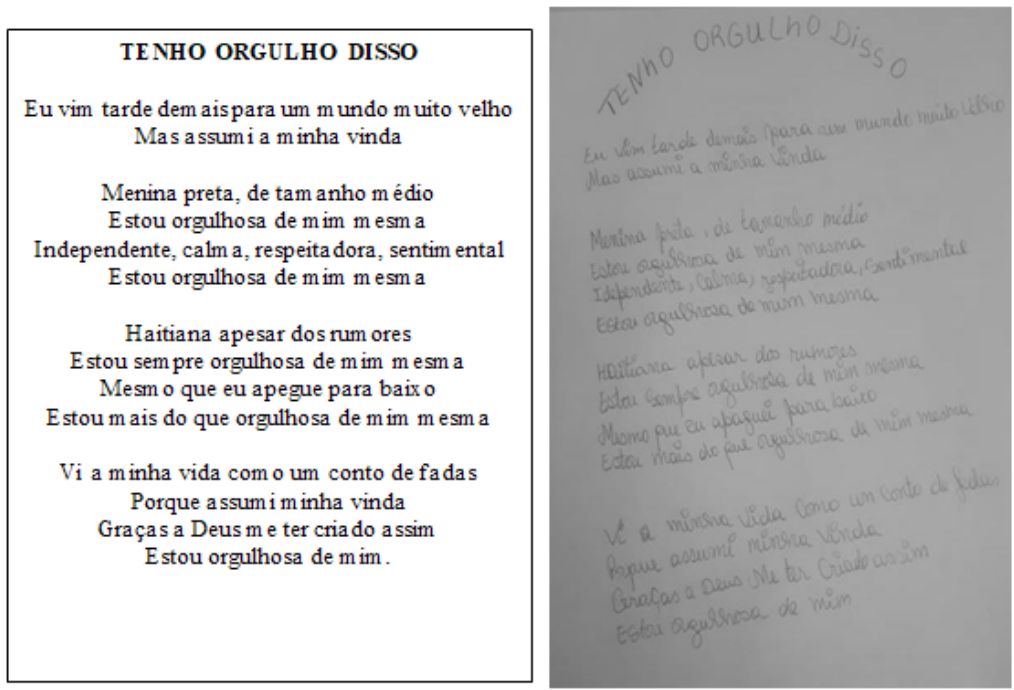

Fonte: Arquivos das autoras

\section{Figura 4 - Ela é uma mulher forte}
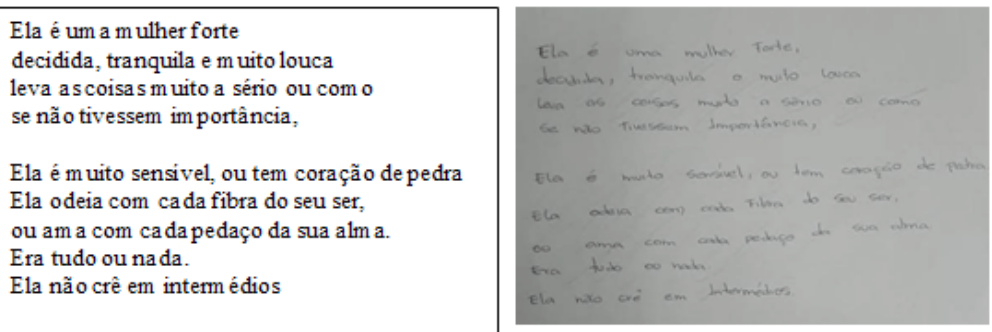

\section{Fonte: Arquivos das autoras}

Paralelamente à produção dos autorretratos nas oficinas de língua portuguesa, nas de história, discutiu-se acerca de identidade; e, nas de criatividade, os alunos produziram autorretratos fotográficos. A Figura 5, que segue, traz algumas dessas fotos. 


\section{Figura 5 - Autorretratos fotográficos}
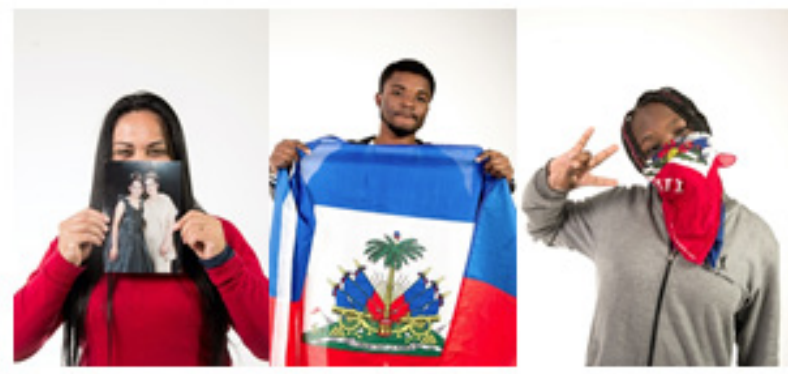

Fonte: Arquivos das autoras

Toda essa diversidade de produções foi exposta no Sarau Culturas do Mundo 2019, evento organizado por todos que se envolvem no projeto. Para o evento, os migrantes também trouxeram comidas típicas e adereços de seus países, o que possibilitou uma noite de diferentes sotaques, sons, ritmos, movimentos, aromas e sabores, unidos por muito afeto, acolhimento e respeito às diferenças. A trilha sonora também foi bem variada, assim como as coreografias, que foram ensinadas e compartilhadas por todos que lá estavam.

A noite também foi de surpresas. Além das atividades organizadas juntamente com os beneficiados do projeto, os migrantes e refugiados também receberam as cartas escritas por seus "amigos secretos brasileiros". A cada carta aberta e lida, um sorriso estampava-se nos rostos; eram cartas de boas-vindas, imbuídas de carinho, com palavras de afeto e gratidão escritas por crianças, o que renovou a esperança de integração dos migrantes e refugiados à comunidade e diminuição do racismo e da xenofobia. 


\section{Figura 6 - Entrega das cartas}
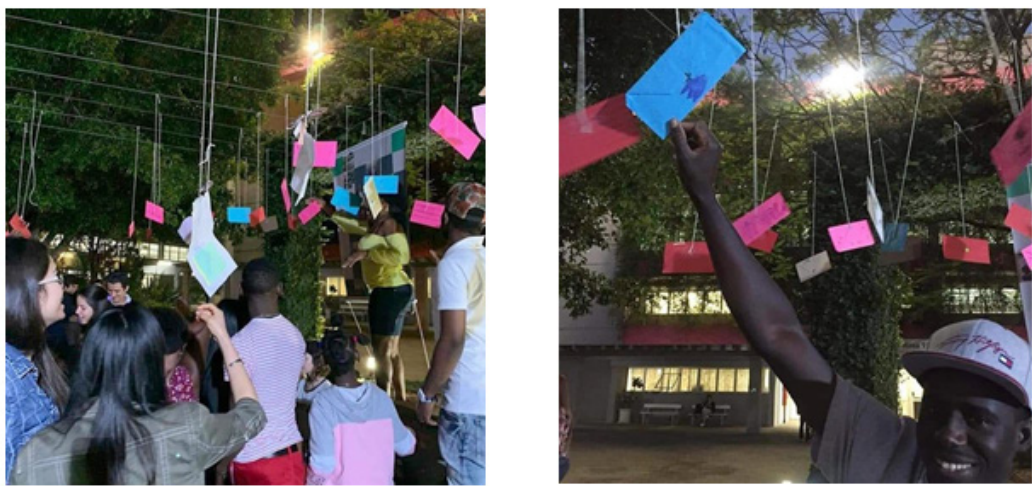

Fonte: Arquivos das autoras

$\mathrm{Na}$ busca por situações reais de uso da língua, no encontro seguinte, propôs-se que as cartas recebidas na semana anterior fossem respondidas. Decidiu-se, ainda, que elas seriam entregues em mãos às crianças, na escola onde estudam. Assim, organizouse, conforme as disponibilidades, o melhor dia e horário, quando representantes dos beneficiados, bolsistas e professores do projeto foram até a escola e, além de entregar as respostas, puderam conversar, brincar e jogar, todos juntos. Foi mais uma manhã memorável e de muitas trocas para todos.

As atividades do $1^{\circ}$ semestre giraram em torno dos autorretratos e estavam, portanto, centralizadas no "eu”. Passado o Sarau e inspirados em sua temática, "NÓS", a união dos “eus", as atividades seguintes foram organizadas a partir desse mote. Inicialmente, discutiu-se acerca de formas de, em português, fazer menção ao pronome pessoal "nós", com ênfase no "a gente". Além disso, averiguaram-se as demais significações do vocábulo, que, além de pronome, é plural de "nó”. Na discussão, outras expressões polissêmicas apareceram, tais como "dar 
corda" (no sentido de permitir que uma conversa flua), "ficar na linha" (telefônica) e afins, até chegar em "criar laço", no sentido de criar um vínculo afetivo com algo ou alguém.

Assim, pensando nos valores afetivos trazidos por esse termo e no poder de humanização da literatura, propôs-se um trabalho a partir de minicontos. Após leituras e análise das especificidades do gênero, os alunos foram desafiados a escrever seus minicontos. Foram aulas de leitura, de escrita, de discussão, encontros multiculturais, mediados pela língua, que já não lhes soava tão estranha assim e, ao mesmo tempo, possibilitava-lhes a criação de laços.

A seguir (Figura 7), compartilham-se alguns minicontos produzidos a partir da temática "Nós = laços". As escritas fizeram menção a uma diversidade de vínculos que se pode ter. Alguns escreveram pensando em quem os recebeu no Brasil, outros, nas famílias que estão distantes em seus países de origem, ainda houve recados de mães para seus filhos ou mesmo textos que pediam por uma sociedade mais empática e equânime. As imagens a seguir trazem alguns desses textos, junto dos nós produzidos quando da discussão acerca de "nós".

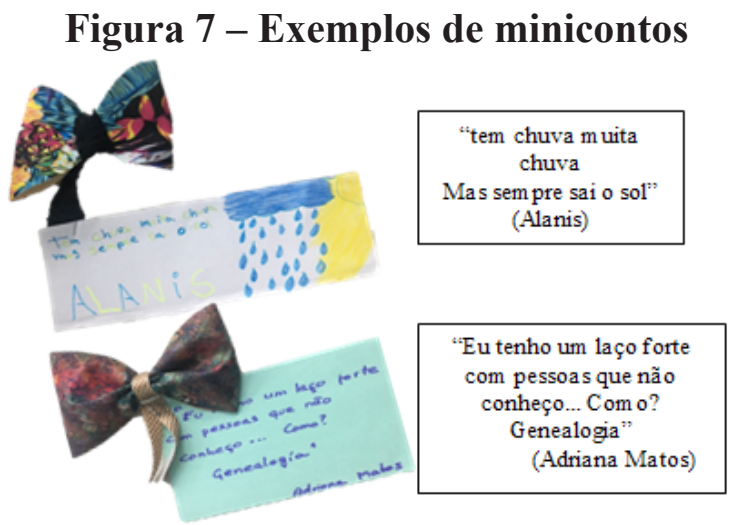

Fonte: Arquivos das autoras. 
Para além de ensinar e aprender português, as aulas de língua portuguesa, no projeto $\mathbf{O}$ mundo em NH, são acolhimento, são encontros de cidadania, em que todos ensinam e todos aprendem. Convém destacar, ainda, que, para os acadêmicos do curso de Letras, representam muito mais que uma vivência extensionista, mas a constituição de professores em formação. Nesse sentido, corrobora-se Santos (2015, p. 4653), ao considerar que "a aproximação do professor em formação com o ambiente real da sala de aula pode vir a construir um processo de formação de professores mais sólido, íntegro e que acompanhe as mudanças sociais que envolvem as gerações". Isso se evidencia quando os discentes envolvidos no projeto são questionados acerca das contribuições da extensão para sua formação:

\begin{abstract}
[...] percebi, no projeto de extensão, o que eu talvez fosse demorar muito a ver se tivesse contato com a sala de aula apenas após a graduação. Entendi o que todas aquelas disciplinas sobre didática diziam com tanto vigor, na prática: a importância de reconhecer o aluno como indivíduo, com suas necessidades e capacidades, com o mundo que traz em si. (Relato de uma das bolsistas do projeto).
\end{abstract}

Muito mais que aliar a teoria à prática, trata-se da compreensão de uma premissa básica para a docência, a empatia, aliada à necessidade de conhecer os alunos, para, a partir de sua bagagem, o professor planejar suas aulas. Cabe destacar, também, a importância da relação professor-aluno, a qual, de acordo com Tardif (2008), envolve processos cognoscitivos e socioemocionais, percebidos na ação de ensinar do professor e no que diz respeito aos vínculos afetivos. Ainda, as vivências no Mundo em NH oportunizam aos acadêmicos algo dificilmente compreendido a partir de experiências de terceiros: o domínio 
de turma - especialmente ao perceberem que a expressão "domínio" se afasta do sentido comum de dominação, tomando uma nova forma, em que professor e aluno constroem juntos o processo de ensino-aprendizagem.

Quanto aos textos produzidos ao longo das aulas? Eles possibilitaram não apenas aprender português, tanto no que diz respeito à escrita como à fala, mas, pela escrita e a fala em uma língua que, aos poucos, vai se tornando familiar, dizer de si, desnudar-se e, dessa forma, permitir que o outro lhe conheça, pela forma como escolheu cada palavra e compôs cada linha, cada verso.

\section{Considerações finais}

É pela linguagem e na linguagem que o sujeito se constitui (BAKHTIN, 2003). Nesse sentido, O mundo em NH é fundamental para que migrantes e refugiados possam se constituir e se integrar à nova sociedade. As oficinas de língua portuguesa, compreendendo o português como língua de acolhimento, são, por sua vez, a possibilidade de esses sujeitos exercerem sua cidadania, integrarem-se na sociedade, no mercado de trabalho e, enfim, como expôs uma das migrantes, "sair da bolha e finalmente existir" nesse novo lugar.

Para além da aprendizagem da língua, as práticas no projeto demonstram a importância do olhar sensível às necessidades básicas dos indivíduos que aqui chegam e buscam, no conhecimento da língua e da cultura do país, também a possibilidade de estabelecer novos vínculos. Essa sensibilidade no fazer pedagógico evidencia-se no olhar atento e na escuta ativa, na busca pelas reais necessidades dos beneficiados do 
projeto, o que significa, também, valorizar seus saberes prévios. Partindo dessa premissa, a elaboração de materiais autênticos e de atividades que possibilitam olhar para si e o outro contribui para uma formação humana, para além daquilo que qualquer manual pedagógico possa sugerir. Ademais, vivências, como a troca de cartas entre crianças de uma escola da cidade e os migrantes beneficiados no projeto, abrem a possibilidade de desconstruir estereótipos negativos muitas vezes vinculados à imagem do migrante/refugiado, na busca por uma sociedade mais equânime e empática.

Por fim, cabe considerar que as práticas docentes estão alicerçadas na concepção epistemológica do professor, na forma como ele concebe "ensinar" e "aprender", assim como em sua visão acerca da aquisição da linguagem. Nesse sentido, compreendendo a linguagem como instrumento de mediação para a constituição do sujeito, as aulas no projeto são organizadas sob o viés dialógico, partindo da premissa de que não há sujeito pronto, mas que ele vai se completando em suas falas e nas falas do outro.

\section{Referências}

ALMEIDA FILHO, José. Carlos Paes. O Português como língua não-materna: concepções e contexto de ensino. São Paulo: Museu da Língua Portuguesa, Estação da Luz, 2005. Disponível em: <http://museudalinguaportuguesa.org.br/wpcontent/uploads/2017/09/ENSINO-COMO-LINGUA-NAOMATERNA.pdf $>$. Acesso em: $1^{\circ}$ mar. 2021.

BAKHTIN, Mikhail. Estética da criação verbal. 4. ed. Tradução P. Bezerra. São Paulo: Martins Fontes, 2003. 
BIGGS, John. TANG, Catherine. Teaching for quality learning at university. 3.ed. [S. l.]: The Society for Research into Higher Education \& Open University Press, 2007.

BUORS, Paule; LENTZ, François. Les littéracies multiples: un cadre de référence pour penser l'intervention pédagogique en milieu francophone minoritaire. Cahiers Franco-Canadiens de l'Ouest, [s. l.], v. 21, n. 1-2, p. 127-150, 2009.

FREIRE, Paulo. Pedagogia da autonomia: saberes necessários a prática educativa. São Paulo: Paz e Terra, 2004.

SANTOS, Camille Anjos de Oliveira; SILVA, Carla Cristie de França; OLIVEIRA, Ana Beatriz Cunha Maia de. Formação de professores: o desafio da prática. Formação de professores: contextos, sentidos e práticas, [s.l.] p. 1-13, 2015. Disponível em: $<$ https://educere.bruc.com.br/arquivo/pdf2017/23961_13445. pdf $>$. Acesso em: 4 mar. 2021.

TARDIF, Maurice. Saberes docentes e formação profissional. 9. ed. Petrópolis: Vozes, 2008. 